\title{
Solar energy density estimation using ANFIS based on daily maximum and minimum temperature
}

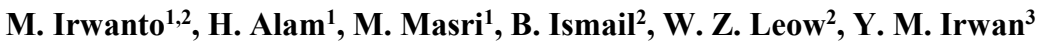 \\ ${ }^{1}$ Departement of Electrical Engineering, Institut Teknologi Medan (ITM), Indonesia \\ ${ }^{2}$ Fellow of center of Excellence for Renewable Energy, Sschool of Electrical System Engineering, Universiti Malaysia \\ Perlis (UniMAP), Malaysia \\ ${ }^{3}$ Centre for Diploma Studies, Universiti Malaysia Perlis (UniMAP), Malaysia
}

\begin{tabular}{l} 
Article Info \\
\hline Article history: \\
Received Apr 21, 2019 \\
Revised Jun 12, 2019 \\
Accepted Jul 3, 2019 \\
\hline
\end{tabular}

Keywords:

Solar energy density Minimum temperature Maximum temperature ANFIS

\begin{abstract}
The data of solar energy density in one area is very important when the area will constructed photovoltaic (PV) system. The data is as preliminary study to decide what the area is suitable or not to be constructed the PV application system. But, sometime the available data is missing because the limitation of weather equipment. An alternative technique for the available data of solar energy density should be done for the continuity of PV application system decision. An estimation technique of solar energy density is one part of good alternative to solve this problem. This paper presents the estimation of solar energy density using Adaptive Neuron Fuzzy Inference System (ANFIS). The ANFIS system has two input data of the measured daily minimum, maximum temperature and difference between maximum and minimum temperature. The measured solar energy density is as target data of ANFIS system. The data is recorded from Medan meteorological station through the web site of world weather online for the year of 2018. The result shows that the average estimated solar energy density is classified in the very high solar energy density and based on the percentage error shows that the estimated solar energy density is acceptable.
\end{abstract}

Copyright (C) 2019 Institute of Advanced Engineering and Science. All rights reserved.

\section{Corresponding Author:}

M. Irwanto,

Departement of Electrical Engineering,

Institut Teknologi Medan (ITM),

52 Gedung Arca Road, Medan, 20217, Indonesia.

Email: mhd-irwanto@itm.ac.id; irwanto@unimap.edu.my

\section{INTRODUCTION}

Solar is fusion radiation process of the sun which its layer can be divided by two parts. They are inner and outer layer. The outer layer is cooler than the inner layer. The outer layer of sun produces radiation and it penetrates the extra-terrestrial and atmosphere region and arrives the surface of earth [1]. The solar can divided by solar power density in unit of $\mathrm{W} / \mathrm{m}^{2}$ and solar energy density in unit of $\mathrm{Wh} / \mathrm{m}^{2}$ or $\mathrm{kJ} / \mathrm{m}^{2}$ or $\mathrm{MJ} / \mathrm{m}^{2}$. The solar power density or solar energy density is very important to determine the performance (voltage, current and power) of photovoltaic (PV) module. The higher solar power density or solar energy density will generated the higher voltage, current and power of PV module. Inversely, the lower solar power density or solar energy density will generated the lower voltage, current and power of PV module.

The effect of solar power density or solar energy density on the performance of PV module has been study by [2], the performance of PV module increases on the condition of constant temperature and the increasing of solar power density or solar energy density. It means that the performance of PV module is proportional to the solar power density or solar energy density. The increasing of the performance of PV module related to the solar power density or solar energy density has been studied by [3] in single axis solar tracking and [4] in the two axis solar tracking. The performance of PV module in the two axis solar tracking 
is better than in the single axis solar tracking. It is due to the solar power density or solar energy density captured by two axis solar tracking is higher compared to the single axis solar tracking. The advantages of solar power density or solar energy density in the applications of PV module have realized in the solar water pump [5], solar PV powered inverter [6-13]. The systems are energized directly by PV module and their operation depend on the solar power density or solar energy density.

A solar PV system is very depend on the solar power density or solar energy density in one area. The solar power density or solar energy density should be measured to obtain its potential to develop solar PV systems [14-20]. But, it is due to the limitation of weather measurement equipment or no equipment, thus it has missing data of solar power density or solar energy density in the area. Some techniques or methods have been developed to estimate the solar power density or solar energy density in one area. A combination Hargreaves method and linear regression has been conducted by [21] to estimate the solar energy density in Perlis, Northern Malaysia. The estimated solar energy density is compared to the measured solar energy density and validated using the statistical analysis of percentage error. The Hargreaves method is also applied to estimate solar energy density in Medan, North Sumatera, Indonesia [22]. The result shows that Medan is categorized in a very high solar energy density and has good potential to develop PV application systems. A modern technique is also applied in the estimation of solar energy using digital numerical by [23]. This technique developed computational method to estimate the potential of solar energy density Eastern Gongju, South Korea. Mathematical modelling of estimated solar energy density is applied by [24] and it predict the output voltage of PV module. Artificial Intelligent (AI) technique of fuzzy logic is applied to estimate the solar energy density based on the meteorological parameter by [25]. The latitude, longitude angle, temperature and mean sun shine are applied in the fuzzy logic to obtain the estimated solar energy density.

This paper presents the solar energy density estimation using Adaptive Neuron Fuzzy Inference System (ANFIS) based on the daily maximum and minimum temperature. The measured data of solar energy density, maximum and minimum temperature are collected from Medan meteorological station through the web site of world weather online. Three estimation condition are conducted as training of ANFIS. The first condition is minimum temperature, maximum temperature and solar energy density, the second condition is maximum temperature, the difference between maximum and minimum temperature and solar energy density, the third condition is the minimum temperature, the difference between maximum and minimum temperature and solar energy density. The estimated and measured solar energy density are validated using statistical analysis of relative percentage error.

\section{RESEARCH METHOD}

This section discusses research method to estimate the solar energy density in Medan, Indonesia. Location and weather condition of Medan, Indonesia is explained briefly based on its latitude angle. The structure of ANFIS to estimate the solar energy density is explained in this section.

\subsection{Location of Medan}

Medan is the fifth largest city in Indonesia has land area of $265.1 \mathrm{~km}^{2}$ and it is located on the latitude of $3.58^{\circ} \mathrm{N}$ as shown in Figure 1 [22]. Medan has average annual temperature of $26.4{ }^{\circ} \mathrm{C}$ and it is relative hot because it is in the equator line. Medan has good potential to be constructed PV system as reported by [22].

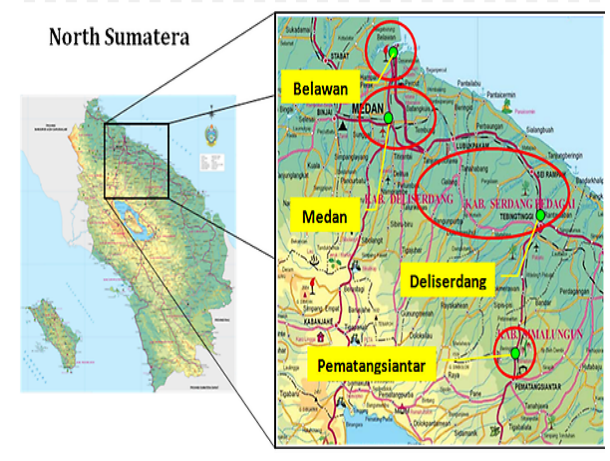

Figure 1. Location of Medan, Indonesia [22] 


\subsection{ANFIS system as estimator of solar energy density}

ANFIS is hybrid artificial intelligent system that it combines the algorithm of artificial neural network (ANN) and fuzzy inference system (FIS) [26]. The object of ANFIS is to enhance the capability of controller or estimator system based on the previous data. The operation of ANFIS follows a fuzzy controller of Takagi-Sugeno [27]. The structure of ANFIS consists of three parts (input data, process and output data) as shown in Figure 2.

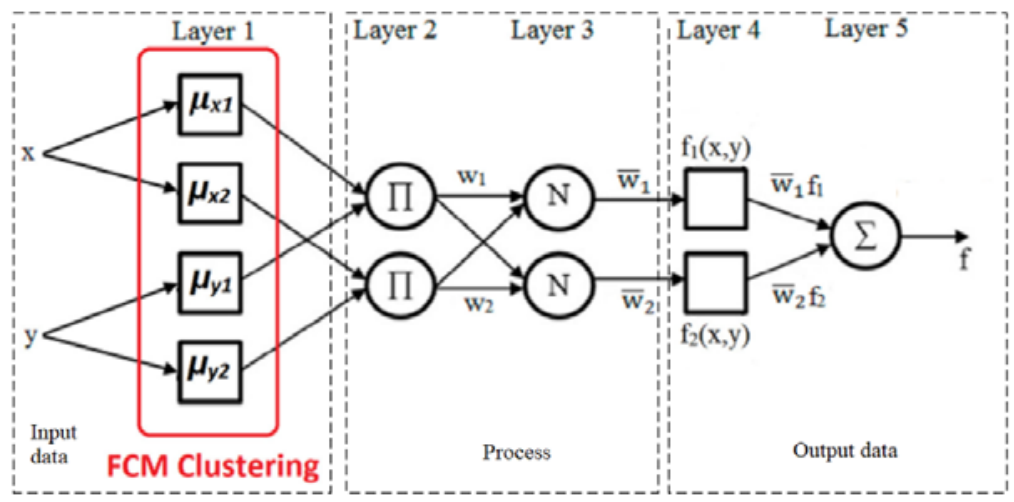

Figure 2. ANFIS structure using fuzzy controller of Takagi-Sugeno [27]

The structure of ANFIS consists of five layers, each layer is constructed by some nodes as node function. The function of each layer is explained below following Figure 2.

a. The first layer (Layer 1) is as fuzzification layer. The input data will be blurred by this layer using membership function.

b. The second layer (layer 2) is as product layer. It multiplies the previous input data performing logic

"AND" as a firing power. The multiplication process can be stated as in Eq. (1).

$w_{1}=\mu_{x 1} \times \mu_{y 1}$

c. The third layer (Layer 3) is as normalized process. It normalizes the firing power. The determination of normalization is given by Eq. (2).

$\bar{w}_{i}=\frac{w_{i}}{w_{1}+w_{2}}$, for $i=1,2$

d. The forth layer (Layer 4) is as defuzzifing layer. The desired output data should be set by the back propagation neural network and it have to match with the target data. The determination of defuzzifing is given by Eq. (3).

$\bar{w}_{1} f_{i}=p_{i} x+q_{i} y+r_{i}$

e. The fifth layer (Layer 5) is as output layer. It is adding the previous defuzzifing.

The weather data needed in the research are minimum temperature, maximum temperature and solar energy density for the year of 2018 collected from Medan meteorological station through the web site of world weather online. The minimum, maximum temperature and the difference between maximum and minimum temperature are input data of ANFIS system. The measured solar energy density is as target data. There are three input data condition as shown in Figure 3(a) created by MATLAB. The first condition is for maximum temperature and minimum temperature, the second condition is for maximum temperature and the 
difference between maximum and minimum temperature, the third condition is the minimum temperature and the difference between maximum and minimum temperature.

Each input data is blurred to be three blurred data as shown in Figure 3(b). Its objective is to assign the difference number of membership function in the fuzzy inference system (FIS). It is due to each input data is blurred to be three data, thus FIS has $3^{2}=9$ (nine) rules as shown in Figure 3(b) and (c). The blurred input data is processed following the rule by ANFIS system and generates an output data as the estimated solar energy density as shown in Figure 3(a) and (b).

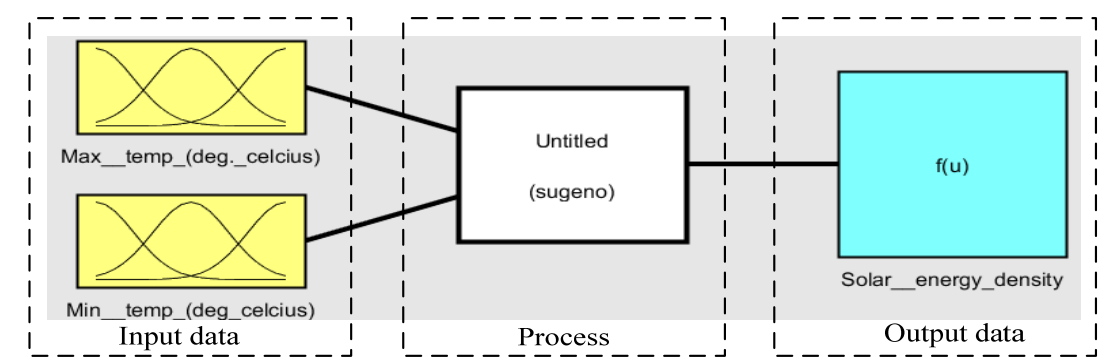

(a) Fuzzy logic designer

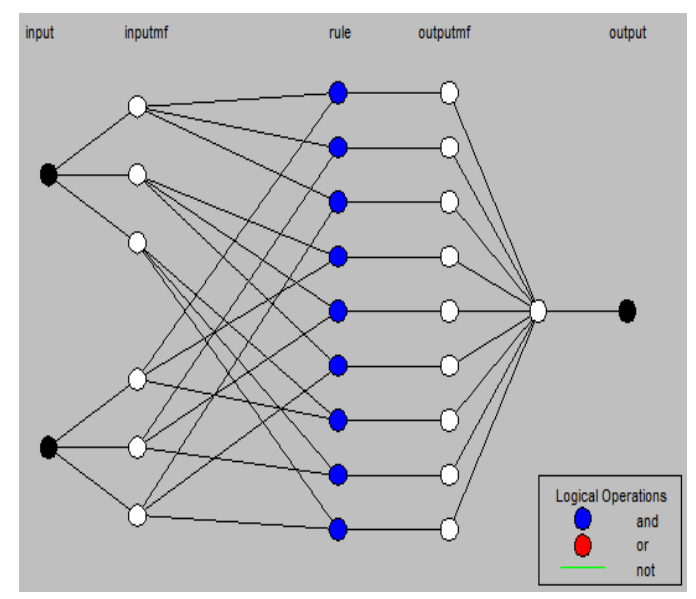

(b) Model of neural network

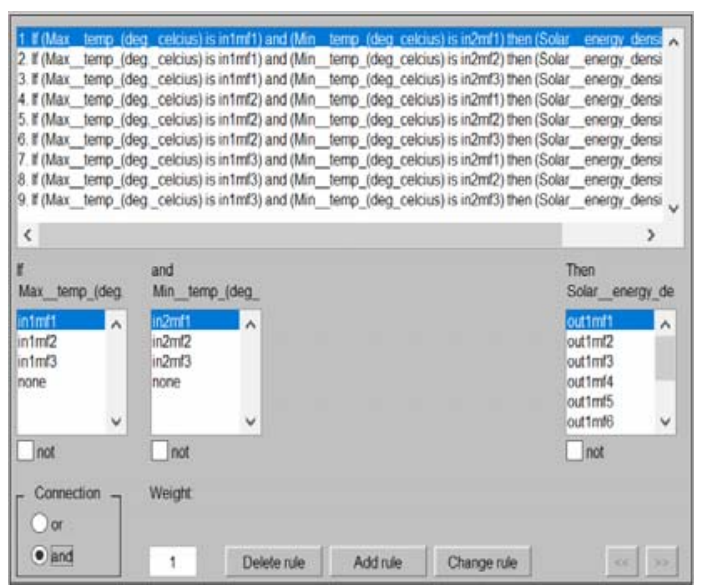

(c) Rule

Figure 3. ANFIS structure in MATLAB

\subsection{Validation of measured and estimated solar energy density}

The measured solar energy density, $R_{\text {mea, } i}$ and estimated solar energy density, $R_{e s t, i}$ are validated using a relative percentage error, $e$ in percent given by Eq. (4) [21]. The value of relative percentage error between $-10 \%$ to $+10 \%$ indicates that the estimated solar energy density is acceptable [21]. The mean percentage error is defined as a percentage deviation of daily measured and estimated solar energy density.

$$
e(\%)=\frac{R_{m e a, i}-R_{e s t, i}}{R_{m e a, i}}
$$

\section{RESULTS AND ANALYSIS}

This section presents and analysis the results of solar energy density using ANFIS system. The input and target data are plotted and analysed. The results of estimated data are interpreted in three scenarios based on the input data. The first scenario is for the input data of minimum and maximum temperature, the second scenario is for the input data of minimum temperature and difference between maximum and minimum temperature, the third scenario is for the input data of maximum temperature and difference between maximum and minimum temperature. Each scenario results the difference profile of estimated solar energy density with also difference minimum, maximum and average solar energy density. 


\subsection{Input and target data of ANFIS system}

Figure 4 shows the daily minimum, maximum and difference between maximum and minimum temperature for the year 2018. These data is used as input data of ANFIS system as shown in Figure 3(a). Every daily minimum, maximum and difference between maximum and minimum temperature is blurred to be three daily minimum, maximum and difference between maximum and minimum temperature with one temperature and the other is multiplied by the performing logic AND. This process is to train them to the target data of measured solar energy density (Figure 5).

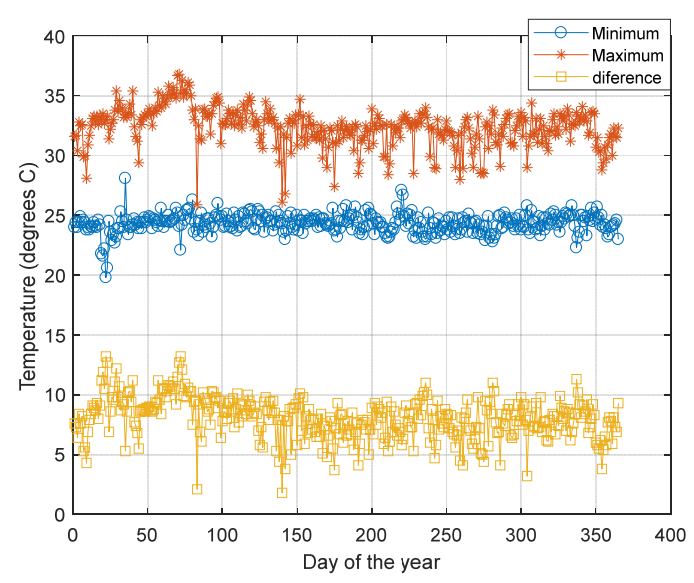

Figure 4. Input data of ANFIS system

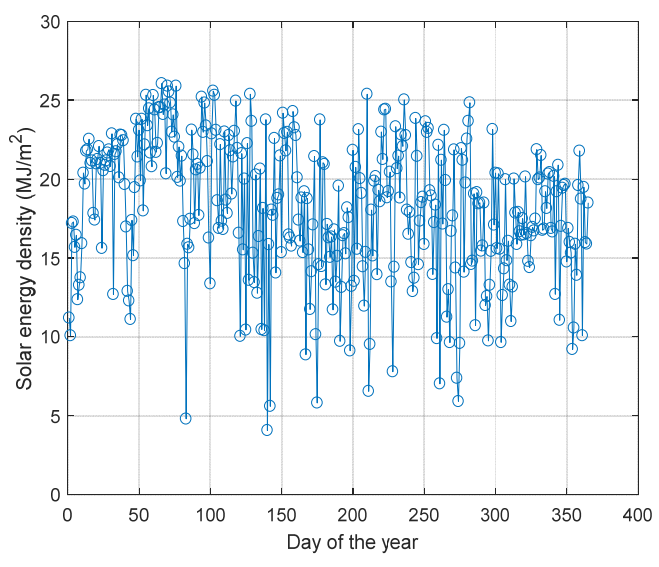

Figure 5. Target data of ANFIS system

The measured solar energy density as target data in Figure 5 has the minimum, maximum and average solar energy density are $4.07 \mathrm{MJ} / \mathrm{m}^{2}, 26.06 \mathrm{MJ} / \mathrm{m}^{2}$ and $18.09 \mathrm{MJ} / \mathrm{m}^{2}$, respectively. The average solar energy density value of $18.09 \mathrm{MJ} / \mathrm{m}^{2}$ is equivalent to $5.03 \mathrm{kWh} / \mathrm{m}^{2}$. It is above $4.00 \mathrm{kWh} / \mathrm{m}^{2}$ and classified in the very high solar energy density [28]. It means that Medan, Indonesia has good potential for developing a $\mathrm{PV}$ power generation system.

\subsection{Estimation of solar energy density}

The estimation of solar energy density is simulated using MATLAB in three scenarios for the difference input data of ANFIS system. The first scenario (scenario 1) is for the input data of minimum and maximum temperature, the second scenario (scenario 2) is for the input data of minimum temperature and difference between maximum and minimum temperature and the third scenario (scenario 3 ) is for the input data of maximum temperature and difference between maximum and minimum temperature.

Figure 6 shows the measured and estimated solar energy density for three scenarios. The values of minimum, maximum and average estimated solar energy density on the first scenario are $2.2818 .09 \mathrm{MJ} / \mathrm{m}^{2}$, $26.67 \mathrm{MJ} / \mathrm{m}^{2}$ and $17.88 \mathrm{MJ} / \mathrm{m}^{2}$, respectively as shown in Table 1 . It has also the percentage error, $e$ of 2.72 $\%$, it indicates that the result of estimated solar energy density thought out of the year 2018 is acceptable. The values of minimum, maximum and average estimated solar energy density on the second scenario are higher than the first scenario, they are $3.13 \mathrm{MJ} / \mathrm{m}^{2}, 26.85 \mathrm{MJ} / \mathrm{m}^{2}$ and $17.96 \mathrm{MJ} / \mathrm{m}^{2}$, respectively as also shown in Table 1 . The result of daily estimated solar energy density is also acceptable following its percentage error, $e$ of $2.71 \%$. The third scenario has the highest minimum estimated solar energy density of $3.95 \mathrm{MJ} / \mathrm{m}^{2}$ compared to the first and the second scenario. But, the maximum estimated solar energy density of 24.39 $\mathrm{MJ} / \mathrm{m}^{2}$ on the third scenario is the lowest value compared to the first and the second scenario. The average estimated solar energy density of $17.95 \mathrm{MJ} / \mathrm{m}^{2}$ on the third scenario is almost same with the first and the second scenario. The percentage error, $e$ of $2.769 \%$ on the third scenario as shown in Table 1 is also still acceptable. The acceptation of estimated solar energy density for the first, second and third scenario is based on the required range value of $-10 \%$ to $+10 \%$ as stated by [21].

The average estimated solar energy density values of $17.88 \mathrm{MJ} / \mathrm{m}^{2}, 17.96 \mathrm{MJ} / \mathrm{m}^{2}$ and $17.95 \mathrm{MJ} / \mathrm{m}^{2}$ for the first, second and third scenario are equivalent to $4.97 \mathrm{kWh} / \mathrm{m}^{2}, 4.99 \mathrm{kWh} / \mathrm{m}^{2}$ and $4.98 \mathrm{kWh} / \mathrm{m}^{2}$, respectively. The values are still above $4.00 \mathrm{kWh} / \mathrm{m}^{2}$, they are still classified in the very high solar energy

Int J Pow Elec \& Dri Syst Vol. 10, No. 4, Dec 2019 : 2206 - 2213 
density. They also can be accepted as one information of solar energy density estimation that give information that Medan has good potential for PV application system.

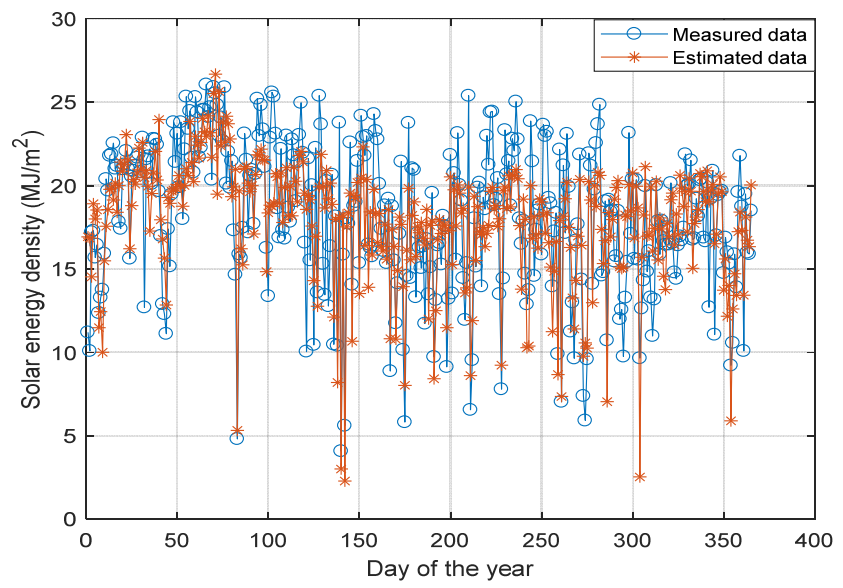

(a) Scenario 1

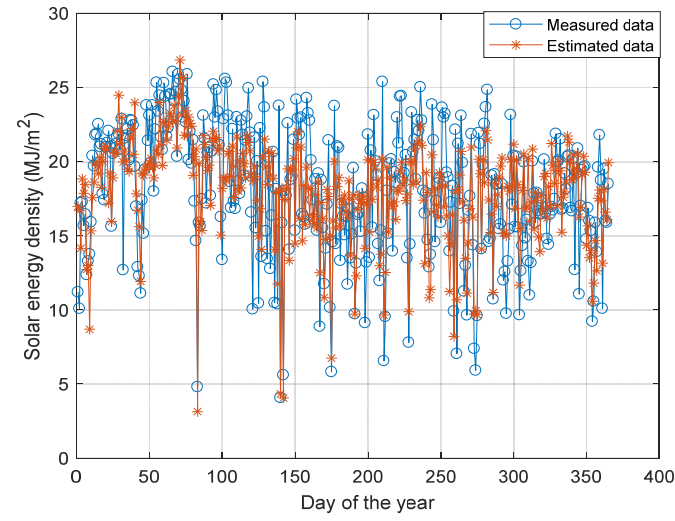

(b) Scenario 2

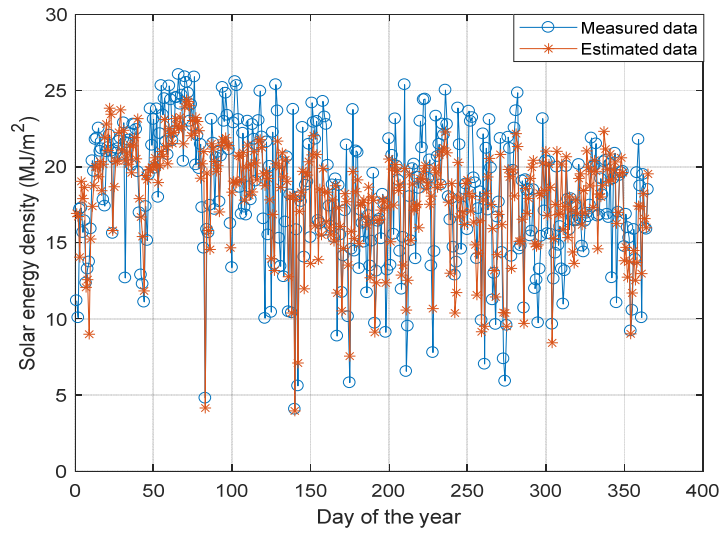

(c) Scenario 3

Figure 6. Measured and estimated solar energy density with various input data of ANFIS system

Table 1. The Minimum, maximum, average and percentage error of estimated solar energy

\begin{tabular}{cccc}
\hline & Scenario 1 & Scenario 2 & Scenario 3 \\
\hline Minimum estimated solar energy density $\left(\mathrm{MJ} / \mathrm{m}^{2}\right)$ & 2.28 & 3.13 & 3.95 \\
Maximum estimated solar energy density $\left(\mathrm{MJ} / \mathrm{m}^{2}\right)$ & 26.67 & 26.85 & 24.39 \\
Average estimated solar energy density $\left(\mathrm{MJ} / \mathrm{m}^{2}\right)$ & 17.88 & 17.96 & 17.95 \\
Percentage error, $e(\%)$ & 2.72 & 2.71 & 2.69 \\
\hline
\end{tabular}

\section{CONCLUSION}

An estimation of solar energy density in Medan, Indonesia has been conducted and analysed using ANFIS system. The input and target data of ANFIS system are taken from Medan meteorological station through the web site of world weather online for the temperature and solar energy density. Some conclusions of this paper can be stated below.

The average measured solar energy density in Medan is $5.03 \mathrm{kWh} / \mathrm{m}^{2}$. It is a value of solar energy density above $4.00 \mathrm{kWh} / \mathrm{m}^{2}$ and it is classified in the very high solar energy density and it also gives good potential for PV application system.

Three scenarios of input data of ANFIS system (minimum and maximum temperature, minimum temperature and difference between maximum and minimum temperature, and the maximum temperature and difference between maximum and minimum temperature) result the average estimated solar energy

Solar energy density estimation using ANFIS based on daily maximum and minimum... (M. Irwanto) 
density are $4.97 \mathrm{kWh} / \mathrm{m}^{2}, 4.99 \mathrm{kWh} / \mathrm{m}^{2}$ and $4.98 \mathrm{kWh} / \mathrm{m}^{2}$, respectively. They are also classified in the very high solar energy density.

Based on the analysis of percentage error shows that the estimated solar energy densities are acceptable because their values are in the required range of $-10 \%$ to $+10 \%$.

\section{ACKNOWLEDGEMENTS}

This work was supported in part by the Indonesian Ministry of Education, Research and Technological under World Class Research Grant for period 2019-2020.

\section{REFERENCES}

[1] I. Daut, et al., "Potential of Solar Radiation and Wind Speed for Photovoltaic and Wind Power Hybrid Generation in Perlis, Northern Malaysia," The 5th International Power Engineering and Optimization Conference (PEOCO2011), Shah Alam, Selangor, Malaysia: pp. 6-7 Jun 2011.

[2] M. Irwanto, et al., "Effect of Solar Irradiance and Temperature on Photovoltaic Module Electrical Characteristics," Proceedings of the International Postgraduate Conference on Engineering (IPCE 2010) 16-17 October 2010, Perlis, Malaysia.

[3] S. H. Chong, et al., "Output energy maximization of a single axis photovoltaic solar tracking system: experimental verification," International Journal of Power Electronics and Drive System (IJPEDS), vol. 10(3), pp. 1655-1661, 2019.

[4] A. A. Abdulrazzaq and A. H. Ali, "Efficiency Performances of Two MPPT Algorithms for PV System With DifferenceSolar Panels Irradiances," International Journal of Power Electronics and Drive System (IJPEDS), vol. 9(4), pp. 1755-1764, 2018.

[5] R. A. Mejeed., "Design of Solar Photovoltaic Pressurized Drip Irrigation Pumping System at Al-salman District in Samawa Governorate," International Journal of Power Electronics and Drive System (IJPEDS), vol. 10(3), pp. 1628-1637, 2019.

[6] I. Dut, et al., "High Power Transformerless Photovoltaic Inverter," Energy Procedia, vol. 36, pp. 465-472, 2013.

[7] M. Irwanto, et al., "Affect of Maximum Voltage Angle on Three-Level Single Phase Transformerless Photovoltaic Inverter Performance," International Journal of Engineering and Applied Sciences, vol. 5, pp. 20-29, 2014.

[8] [8] M. Masri, et al., "Effect of Maximum Voltage Angle on Inverter Performance Applied in Uninterrupted Power Supply (UPS)," Applied Mechanics and Materials, vol. 793, pp. 304-308, 2015.

[9] M. Irwanto, et al., "Analysis of AC Voltage and Current Waveform Distortion on SPWM Transformerless Photovltaic Inverter," Far East Journal of Electronics and Communications, vol. 17(5), pp. 1167-1176, 2017.

[10] H. Alam, et al., "Analysis of AC Voltage Waveform on Changeover of Transfer Switch on Photovltaic Powered Uninterruptible Power Supply System," Far East Journal of Electronics and Communications, vol. 17(5), pp. 1029$1035,2017$.

[11] H. Alam, et al., "Output Characteristics of Photovoltaic Module in Medan Based on Estimated Solar Irradiance Using Hargreaves Method for Application Assessment of Transformerless Photovoltaic Inverter," AIP Conference Proceedings, vol. 177, 2016.

[12] M. Masri. et al.,"Optimum Sizing of Photovoltaic Powered Uninterruptible Power Supply," Far East Journal of Electronics and Communications, vol. 17(5), pp. 1111-1117, 2017.

[13] M. Masri. et al.,"Solar Radiation Potential as Energy Source of Photovoltaic Powered Uninterrupted Power Supply in Perlis, Northern Malaysia," IOSR Journal of Electrical and Electronics Engineering (IOSR-JEEE), vol. 6, pp. 31-36, 2016.

[14] O. L. Lapeña and R. P. Areny, "Solar Energy Radiation Measurement with a Low-Power Solar Energy Harvester," Computers and Electronics in Agriculture, vol. 151, pp. 150-155, 2015.

[15] A. N. Syafwati. et al.,"Potential of Solar Energy Harvesting in Ulu Pauh, Perlis, Malaysia using Solar Radiation Analysis Studies," Energy Procedia, vol. 14, pp. 1503-1508, 2012.

[16] Y.M. Irwan. et al.,"Potential of Solar Radiation and Ambient Temperature as an Alternative Energy in Perlis," Applied Mechanics and Materials, vol. 793, pp. 323-327, 2015.

[17] M. Irwanto.,"Solar Irradiance and Optimum Tilt Angle of Photovoltaic Module in Tanjung Morawa, North Sumatera, Indonesia," International Journal of Research in Advanced Engineering and Technology, vol. 1, pp. 3438,2015 .

[18] A. George. et al, "Review of Solar Energy Development in Kenya: Opportunities and Chalanges," Renewable Energy Focus, vol. 29, pp. 123-140, 2019.

[19] H. P. Dasari. et al, "High-resolution Assessment of Solar Energy Resources Over the Arabian Peninsula," Applied Energy, vol. 248, pp. 354-371, 2019.

[20] Y. F. Nassar. et al, "Assessment of Solar Energy Potential in Gaza Strip-Palestine," Sustainable Energy Technologies and Assessments, vol. 31, pp. 318-328, 2019.

[21] I. Daut. et al., "Combination of Hargreaves Method and Linear Regression as a New Method to Estimate Solar Radiation in Perlis," Northern Malaysia, Solar Energy, vol. 85, pp. 2871-2880, 2011.

Int J Pow Elec \& Dri Syst Vol. 10, No. 4, Dec 2019 : 2206 - 2213 
[22] K. Saleh. et al., "Estimation of Solar Irradiation in Medan Using Hargreaves Method Based on Minimum and Maximum Temperature for Potential Assessment of Photovoltaic Power Generation," Advanced Science Letters, vol. 23(5), pp. 4463-4466, 2017.

[23] J. Jung. et al.,"Digital Numerical Map-Oriented Estimation of Solar Energy Potential for Site Selection of Photovoltaic Solar Panels on National Highway Slopes," Applied Energy, vol. 242, pp. 57-68, 2019.

[24] Z. H. Ali. et al.,"Modeling Solar Modules Performance Under Temperature and Solar Radiation of Western Iraq," International Journal of Power Electronics and Drive System (IJPEDS), vol. 9(4), pp. 1842-1850, 2018.

[25] M. Rijwan. et al.,"Fuzzy Logic Based Modeling and Estimation of Global Solar Energy Using Meteorological Parameters," Energy, vol. 70, pp. 685-691, 2014.

[26] E. Adigüzel. et al., "Prediction of dust particle size effect on efficiency of photovoltaic modules with ANFIS: An experimental study in Aegean region, Turkey," Solar Energy, vol. 177, pp. 690-702, 2019.

[27] T. Takagi and M. Sugeno, "Fuzzy identification of systems and its applications to modeling and control," IEEE Trans. Syst., Man, Cybernet. SMC-15, pp. 116-132, 1985.

[28] R. Laleman. et al., "Life Cycle Analysis to Estimate The Environment Impact of Resedential Photovltaic Systems in Region with Low Solar Radiation," Renewable and Sustainable Energy Review, vol. 15, pp. 267-281, 2011.

\section{BIOGRAPHIES OF AUTHORS}

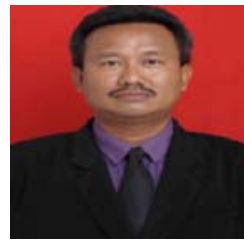

M. Irwanto received his PhD degree in Electrical System Engineering from Universiti Malaysia Perlis (UniMAP), Malaysia in 2012. He is currently a lecturer in Department of Electrical Engineering, Institut Teknologi Medan (ITM). He is also fellow of Centre of Excelence for Renewable Energy (CERE), School of Electrical System Engineering, Universiti Malaysia Perlis (UniMAP). His research interest includes power electronic, electrical power system stability and solar energy and photovoltaic application system.

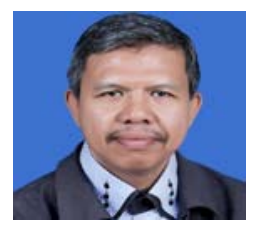

H. Alam received his $\mathrm{PhD}$ degree in Electrical System Engineering from Universiti Malaysia Perlis (UniMAP), Malaysia in 2019. He is currently a lecturer in Department of Computer Engineering, Institut Teknologi Medan (ITM). His research interest includes artificial intellegent system, solar energy and photovoltaic application system.

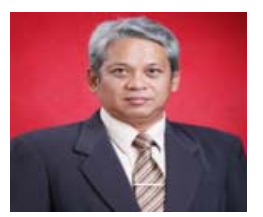

M. Masri received his $\mathrm{PhD}$ degree in Computer Engineering from Universiti Malaysia Perlis (UniMAP), Malaysia in 2016. He is currently a lecturer in Department of Computer Engineering, Institut Teknologi Medan (ITM). His research interest includes artificial intellegent system, solar energy and photovoltaic application system.

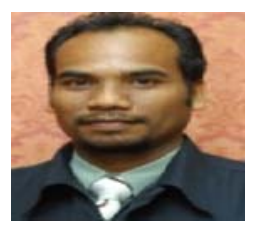

B. Ismail received his $\mathrm{PhD}$ degree in Electrical System Engineering from Universiti Malaysia Perlis (UniMAP), Malaysia in 2015. He is currently a lecturer in School of Electrical System Engineering, Universiti Malaysia Perlis (UniMAP). He is also Cheif of Centre of Excelence for Renewable Energy (CERE), School of Electrical System Engineering, Universiti Malaysia Perlis (UniMAP). His research interest includes power electronic and renewable energy system.

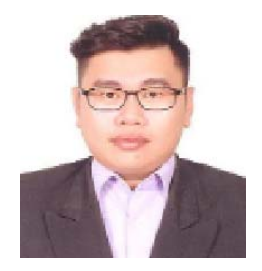

W. Z. Leow received his $\mathrm{PhD}$ degree in Electrical System Engineering from Universiti Malaysia Perlis (UniMAP), Malaysia in 2018. He is currently a lecturer in School of Electrical System Engineering, Universiti Malaysia Perlis (UniMAP). He is also member of Centre of Excelence for Renewable Energy (CERE), School of Electrical System Engineering, Universiti Malaysia Perlis (UniMAP). His research interest includes cooling system and renewable energy system.

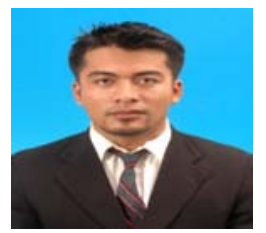

Y. M. Irwan has his B. Elect.Eng. (Hons), MSc and $\mathrm{PhD}$ degree in Electrical System Engineering from University Malaysia Perlis in 2007, 2010 and 2015, respectively. In 2010, he joined the Department of Electrical System Engineering at University Malaysia Perlis as a lecturer. His areas of interest include power quality, adjustable-speed drives, energy conversion and power system applications. He has authored and coauthored more than 100 technical papers in the national, international journal and conferences. 